\title{
ARTICLES
}

Submitted 12.31.2013. Approved 06.30.2014

Evaluated by double blind review process. Scientific Editor: Antonio Domingos Padula

DOI: http://dx.doi.org/10.1590/So034-759020150306

\section{SUPPLY CHAIN RESILIENCE ANALYSIS: A BRAZILIAN AUTOMOTIVE CASE}

\author{
Análise da resiliência na cadeia de suprimentos: um caso automotivo brasileiro \\ Análisis de la resiliencia en la cadena de suministros: un caso automotriz \\ brasileño
}

\begin{abstract}
Supply chain (SC) resilience and flexibility are important research topics receiving growing attention. However, the academic literature needs empirical studies on SC resilience capable of investigating the inter-organizational components of flexibility along different tiers. Therefore, this paper analyzes the main lack of flexibilities in three Brazilian automotive SCs that limit their resilience and therefore their capacity to better support and meet the demand changes in the marketplace. A multi-tier case study approach is adopted. Research findings identify lack of flexibilities in different tiers that inhibit the SC resilience as well as manufacturing and SC flexibilities that build SC resilience. The findings also highlight that the same SC may have the flexibility to be resilient for one of its products but not for another product, what sheds new lights on the academic literature. Finally, flexible SCs should be designed to increase SC resilience to cope with mishaps as significant demand changes.
\end{abstract}

KEYWORDS | Supply chain resilience, flexibility, supply chain flexibility, automotive industry, case study.

\section{RESUMO}

Resiliência na cadeia de suprimentos e flexibilidade são temas de pesquisa que tem tido crescente atenção. Entretanto, a literatura acadêmica necessita de estudos empíricos sobre resiliência em cadeias de suprimentos capazes de investigar os componentes interorganizacionais de flexibilidade ao longo de seus diferentes elos. Assim, este artigo analisa a falta de flexibilidades em três cadeias de suprimentos da indústria automobilística brasileira que limitam sua resiliência e, portanto, sua capacidade de atender às mudanças de demanda no mercado. Uma abordagem multi-elos é adotada. Os resultados da pesquisa identificaram falta de flexibilidade em diferentes elos das cadeias de suprimentos que inibem sua resiliência. Os resultados também apontam que uma mesma cadeia pode ter flexibilidade para ser resiliente para um de seus produtos, mas não para outro, o que sugere novas frentes de pesquisa. Finalmente, cadeias de suprimentos flexíveis devem ser concebidas provendo resiliência para lidar com entraves como mudanças significativas de demanda.

LUIZ FELIPE SCAVARDA

If.scavarda@puc-rio.br

Professor at Pontifícia Universidade

Católica do Rio de Janeiro,

Departamento de Engenharia

Industrial - Rio de Janeiro - RJ, Brazil

\section{PAULA SANTOS CERYNO}

paulaceryno@hotmail.com

Professor at Universidade Federal do Estado do Rio de Janeiro, Escola de Engenharia de Produção - Rio de Janeiro - RJ, Brazil

\section{SILVIO PIRES}

sripires@unimep.br Professor at Universidade Metodista de Piracicaba, Faculdade de Gestão e Negócios - Piracicaba - SP, Brazil

\section{KATJA KLINGEBIEL}

katja.klingebiel@fh-dortmund.de Professor at University of Applied Sciences and Arts/ Fachhochschule Dortmund, Faculty of Economic Dortmund, Germany
PALAVRAS-CHAVE / Resiliência na cadeia de suprimentos, flexibilidade, flexibilidade na cadeia de suprimentos, indústria automotiva, estudo de caso.

\section{RESUMEN}

Resiliencia en la cadena de suministros y flexibilidad son temas de estudio que han tenido una creciente atención. Sin embargo, la literatura académica necesita estudios empíricos sobre resiliencia en las cadenas de suministros capaces de investigar los componentes interorganizacionales de flexibilidad a lo largo de sus diferentes eslabones. De esta manera, este artículo analiza la falta de flexibilidades en tres cadenas de suministros de la industria automovilística brasileña que limitan su resiliencia y, por lo tanto, su capacidad de atender a los cambios de demanda en el mercado. Para este fin se adopta un abordaje multieslabones. Los resultados del estudio identificaron la falta de flexibilidad en diferentes eslabones de las cadenas de suministros que inhiben su resiliencia. Los resultados también señalan que una misma cadena puede tener flexibilidad para ser resiliente en uno de sus productos, pero no para otro, lo que sugiere nuevos frentes de investigación. Finalmente, se deben ser concebir cadenas de suministros flexibles proveyendo resiliencia para tratar con obstáculos como cambios significativos de demanda.

PALABRAS CLAVE / Resiliencia en la cadena de suministros, flexibilidad, flexibilidad en la cadena de suministros, industria automotriz, estudio de caso. 


\section{INTRODUCTION}

Typically, a supply chain (SC) is a complex network of enterprises that can experience continual turbulence, creating the potential for unpredictable disruptions (Pettit, Fiksel, \& Croxton, 2010). SC disturbances are increasing in number and frequency, affecting normal operations and stability and, consequently, $\mathrm{SCs}$ ability to meet commitments. Therefore, SCs must be resilient to overcome their vulnerabilities, responding effectively to the negative impacts of disturbances (Carvalho, Barroso, Machado, Azevedo, \& Cruz-Machado, 2012). As a result, there has been growing attention in the literature for what has been called SC resilience (Pettit, Fiksel, \& Croxton, 2010; Ponis \& Koronis, 2012).

The concept of resilience has been traditionally studied in different disciplines, such as Ecology, Engineering, Psychology and Economics, but in the business context, the SC resilience concept is relatively new, and theoretical justifications are still in their infancy (Ponomarov \& Holcomb, 2009; Juttner \& Maklan, 2011; Ponis \& Koronis, 2012: Soni, Jain, \& Kumar, 2014). The key elements of $\mathrm{SC}$ resilience and the relationships among them are still poorly understood (Ponomarov \& Holcomb, 2009). The available literature on $\mathrm{SC}$ resilience is informative and is primarily focused on presenting several theoretical viewpoints of the phenomenon (Sheffi, 2001; Christopher \& Lee, 2004; Christopher and Towill, 2001; Bhamra, Dani, \& Burnard, 2011; Juttner \& Maklan, 2011); more empirical studies are needed on the subject (Juttner \& Maklan, 2011; Bhamra, Dani, \& Burnard, 2011; Wieland \& Wallenburg, 2013).

According to Datta, Christopher and Allen (2007), SC resilience is not just the ability to recover from mishaps but is a proactive, structured and integrated exploration of capabilities within the SC to cope with unforeseen events. These capabilities are attributes that enable an enterprise to anticipate and overcome disruptions by preventing an actual disruption, mitigating the effects of a disruption, or enabling adaptation following a disruption (Pettit, Fiksel, \& Croxton, 2010). An example of such a capability is flexibility. Sheffi and Rice (2005) noted that the most important step that companies and/or SCs can take to increase their resilience fundamentally and efficiently is to increase their flexibility. As they move to build flexibility to respond to demand and supply volatility, they are also building in resilience, and vice versa. Therefore, flexibility is considered one of the key elements of resilience (Christopher \& Peck 2004; Juttner \& Maklan, 2011).

The basic flexibility principle for resilience is to design a more flexible process that can operate under various disturbances without the necessity to return to the previous conditions un- der disturbance as long as the constraints and specifications are met (Dinh, Pasman, Gao, \& Mannan, 2012). As current business competitive models embrace the SC, the flexibility debate is extended beyond the enterprise boundaries in what is described by Fatemi (2010) as: "Now-a-days researchers emphasize it is important to look beyond the flexible factory to the flexible SC.... As the $\mathrm{SC}$ extends beyond the enterprise, $\mathrm{SC}$ flexibility must also extend beyond one firm's internal flexibility (p. 140)". According to Moon, Ying and Ngai (2012), SC flexibility involves the application of SC resources according to marketing dynamics and requires firms to develop cross-functional and cross-company strategies that eliminate bottlenecks and create a level of performance that allows firms to strengthen their competitive advantage in an uncertain market. One major limitation of the literature is that most of the previous studies on SC flexibility have been conducted within the confines of a single firm, thereby neglecting other important aspects of a SC (Moon, Ying, \& Ngai, 2012). Various avenues exist for future research, such as the development of empirical studies capable of investigating the inter-organizational components of SC flexibility along different tiers (Stevenson \& Spring, 2007; Chandra \& Grabis, 2009; Fatemi 2010).

The automotive industry has been considered by many academics and practitioners as a place to develop, introduce, monitor, review and improve business concepts, especially in the SC management discipline, becoming a reference for many other industrial sectors. Countries like Brazil, China and India have emerged as major producers and consumers of vehicles, resulting in a growing interest in investigating automotive SCs in these countries (Pires \& Sacomano Neto, 2008; Scavarda, Reichhart, Hamacher, \& Holweg, 2010). However, in recent years, the significant growth of vehicle demand in Brazil (influenced by the government policies of incentives) has not always been followed at the same pace by the supply capacity of industry suppliers or by the availability of a logistics infrastructure, especially in the case of imported components. Thus, the country has increased the risk of disruptions in assembly lines and/or has not adequately met the demands of vehicle buyers (Pires, Weinstock, \& Andrade, 2013). In addition, this variation in demand and production volume is also evident when the latest data from the sector in the country is considered. Current data from the Brazilian Automakers' Association - Associação Nacional dos Fabricantes de Veículos Automotores (Anfavea, 2014) - show that in 2013, the industry produced $10 \%$ more vehicles than in 2012. However, in the first five months of 2014, it produced $13 \%$ less than during the same period in 2013. In this context, SC resilience and flexibility are key elements to be improved.

Therefore, the purpose of this paper is to examine the main lack of flexibilities in three Brazilian automotive SCs that 
limit their resilience and therefore their capacity to better support and meet the demand changes in the marketplace. To achieve this goal, the paper is structured as follows. First, the existing literature on SC resilience and flexibility is reviewed, followed by the description of the research design. Subsequently, the research findings are presented and discussed. The last section provides the authors' conclusions and final remarks.

\section{THEORETICAL BACKGROUND}

This section first offers a review of SC resilience research and then flexibility as an enabler to reach this resilience.

\section{Supply Chain Resilience}

The concept of resilience has been studied throughout the years in different disciplines, but the concept remains relatively undeveloped (Dinh, Pasman, Gao, \& Mannan, 2012). Resilience is a term borrowed from Materials Engineering that has been recently used in the SC Risk Management literature. It describes the ability of a system to recover its initial state after a stressful situation, without any change in its nature (Christopher \& Peck, 2004; Klibi \& Martel, 2012). Within the business context, the concept of resilience was introduced more recently. The unstable and highly competitive business environment, coupled with the emergence of natural and man-made hazards in a volatile environment of financial instability and on-going crisis, have put $\mathrm{SC}$ resilience among the forefront concepts in $\mathrm{SC}$ research (Ponis \& Koronis, 2012). In line with this discussion, organizational resilience can be understood as "the capacity for an enterprise to survive, adapt, and grow in the face of turbulent change" (Fiksel, 2006, p.16)

A company's resilience is a function of its competitive position and the responsiveness of its SC (Sheffi \& Rice, 2005). The awareness regarding the magnitude of losses (direct and indirect) resulting from SC disruptions increased the interest in SC Resilience (Bakshi \& Kleindorfer, 2009). Thus, SC Resilience is considered a critical component of SC risk management (Ponomarov \& Holcomb, 2009) and a relatively new and underexplored research area in management as a whole (Ponis \& Koroni, 2012). SC Resilience can be defined as the ability of a SC to cope with the consequences of unavoidable risk events to return to its original operations or to move to a new, more desirable state after being disturbed (Christopher \& Peck, 2004; Peck, 2005; Ponomarov \& Holcomb, 2009).

Christopher and Peck (2004) develop a managerial agen$\mathrm{da}$ for the identification and management of SC risk, with rec- ommendations to improve the resilience of SCs. The authors conclude that resilience implies flexibility and agility, and its implications extend beyond process redesign to fundamental decisions on sourcing along with the establishment of more collaborative SC relationships, based on greater transparency of information. Sheffi and Rice (2005) advocate a strategy approach to develop resilience that represents an opportunity to introduce flexibility in the $\mathrm{SC}$ and, by doing so, create resilience. They predicate that flexibility not only increases resilience in times of disruption but also creates benefits and operational efficiencies in the normal course of business. Datta, Christopher and Allen (2007) study the SC behavior under uncertainty and identify the dominant strategies responsible for improving $\mathrm{SC}$ resilience. They conclude that decentralization, information sharing, agility, flexibility, redundancy, collaboration and learning strategies improve resilience.

Pettit, Fiksel and Croxton (2010) build on lessons learned from SC disruptions to create a conceptual framework for evaluating and improving SC resilience. They assert that the balance between capabilities and vulnerabilities creates a firm's true competitive advantage. Juttner and Maklan (2011) conceptualize SC resilience and empirically identify and explore its relationship with the related concepts of SC vulnerability and SC risk management. The authors indicate that SC risk management seems to enhance SC resilience by improving its flexibility, visibility, velocity and collaboration capabilities. Ponis and Koronis (2012) conceptualize SC resilience and identify which SC capabilities can support the containment of disruptions as well as how these capabilities affect SC Resilience. The authors assert that the most grounded antecedents of SC resilience are agility, flexibility, velocity, visibility, availability, redundancy, mobilization of resources, collaboration and SC structure knowledge.

Carvalho, Barroso, Machado, Azevedo and Cruz-Machado (2012) present a SC simulation study for a real case concerned with a Portuguese automotive SC. The authors conclude that both flexibility and redundancy strategies are effective in reducing the negative effects of the disturbance on SC performance. However, when the flexibility strategy is applied, the total cost of the SC is less than the redundancy strategy, and the lead time ratio is better. Wieland and Wallenburg (2013) explore the resilience domain and investigate relational competencies effect on resilience and resilience effect, on a SC's customer value. They note that communicative and cooperative relationships have a positive effect on resilience, while integration does not have a significant effect.

Finally, flexibility as one of the key elements of resilience (Christopher \& Peck, 2004; Sheffi \& Rice, 2005; Juttner \& Maklan, 2011; Ponis \& Koronis, 2012), is discussed next. 


\section{Flexibility}

Flexibility is commonly associated with the ability to change or react (Upton, 1994; De Toni \& Tonchia, 1998); therefore, a central aspect of flexibility is the object of change. This aspect is commonly referred to as the flexibility type (Slack, 1987; Suarez, Cusumano, \& Fine, 1996). According to Slack (1987), there are four types of flexibility in a manufacturing system: product, mix, volume and delivery (Slack, 1987). Product flexibility refers to the system's ability to introduce new products or make modifications to existing products. Mix flexibility denotes the ability of a system to alter its product mix (keeping overall output stable), while volume flexibility refers to a system's ability to change its overall production volume. Finally, delivery flexibility denotes a system's ability to change planned delivery times (or sequences) for existing orders. The flexibility concept may be complemented by a range of inter-organizational flexibility types. According to Stevenson and Spring (2007), these include re-configuration flexibility as the potential to re-align or re-invent the SC, relationship flexibility as the ability to build collaborative relationships both up and downstream, and logistics flexibility as the potential to rapidly send and receive products cost efficiently. Fatemi (2010) proposes postponement flexibility as the capability of keeping products in their generic form as long as possible downstream in the SC to incorporate the customer's product requirements in later stages, and sourcing flexibility as the ability to find another supplier for each specific component or raw material. Sourcing flexibility is also defined as the ability to quickly change inputs or the mode of receiving inputs, such as part commonality, modular product design, multiple uses, supplier contract flexibility and multiple sources (Pettit, Fiksel, \& Croxton, 2010). Flexibility in order fulfillment is the ability to quickly change outputs or the mode of delivering outputs, such as alternate distribution channels, risk pooling / sharing, delayed commitment, and re-routing of requirements (Pettit, Fiksel, \& Croxton 2010). Upton (1994) suggested a distinction between "external" and "internal" flexibility. External flexibility refers to the flexibility types that matter to the system's customers, while internal flexibility comprises all types that are internal to the system and are used to deliver external flexibility.

The current literature on SC flexibility covers a range of foci. For example, Fisher (1997), Randall and Ulrich (2001), Lee (2002), Qi, Boyer and Zhao (2009) study the relationship between SC structure, product structure and external environment. Berry and Cooper (1999) conclude that flexibility does not always lead to higher profitability; the level of flexibility needs to be aligned with the requirements placed upon the SC. Anoth- er focus of SC flexibility is the design of SCs. Chandra and Grabis (2009) present potential tools and techniques for designing and modeling flexibility in SCs, and Graves and Tomlin (2003) study how SCs can cost-efficiently deliver mix flexibility based on a mathematical model and subsequent simulation. Tsay and Lovejoy (1999) and Liao, Hong, and Rao (2010) have contributed to the topic of SC flexibility measurement by studying how to quantify flexibility and its impact on SC performance. Gosling, Purvis and Naim (2010) have examined how buying organizations can configure their supply networks to achieve SC flexibility, while Lee, Yeung, and Cheng (2009) have studied supplier alliances in environment uncertainty, showing their impact on flexibility and suggesting that firms should avoid close supplier relationships in uncertainty environments to gain flexibility in switching suppliers.

Despite the increasing importance of the topic, few empirical contributions investigate the structure of SCs from a flexibility viewpoint. Chang, Chen, Lin, Tien, and Sheu (2006) extend the knowledge on manufacturing flexibility regarding its integration with SC activities by focusing on supplier involvement in the motherboard industry in Taiwan. They find that supplier involvement plays a major role in the development and performance of a firm's manufacturing flexibility. Sawhney (2006) investigates the interplay between uncertainty and flexibility in the printed circuit board industry and discusses how the processes in a SC interact to deliver flexibility. This author proposes a transformation framework that articulates how managers can configure flexibility simultaneously between the proactive and the reactive uses that coexist in a firm's day-to-day operations. Sánchez and Pérez (2005) treat flexibility of SC partners as a primary input to explore the relationship between the dimensions of SC flexibility and firm performance in Spanish automotive suppliers. They show that companies enhance more basic flexibility capabilities (at the shop floor level) rather than aggregate flexibility capabilities (at the customer-supplier level). More recently, Moon, Ying, and Ngai (2012) have determined how an instrument with a set of multi-item measurement scales representing the SC flexibility construct could be developed and validated analyzing many firms within the textile and clothing industry in China. The empirical study of Avittathur and Swamidass (2007) investigates the effect of the match between the buyer and supplier flexibilities on the performance of U.S. manufacturing plants located in India. Stevenson and Spring (2009) investigated the specific inter-firm practices that are used to achieve increased flexibility in multi-tier pairs and in the wider SC, and how these practices and effects interact. However, they did not examine the lack of flexibility that limits the SC ability to be resilient. 


\section{RESEARCH DESIGN}

This research adopted a case study approach, as it is appropriate for investigations of contemporary phenomena within their real life context, particularly when the boundaries between them are not clearly defined. Thereby, this approach is recommended for current themes and situations where the researcher observes the facts and attempts to understand, systematize and analyze them (Voss, Tsikriktis, \& Frohlich, 2002; Yin, 2008).

Regarding the definition of the case to be studied, Voss, Tsikriktis, and Frohlich (2002) state that the traditional way of sampling is to identify a population and select a random or stratified sample from it. However, in case studies, this selection is usually based on distinct and intentional criteria. One of the main ways to conduct sampling is by selecting representative cases. Therefore, this study took place in three SCs, two of which are part of the group of five SCs with higher vehicles sales volumes in Brazil in recent years. As any finding or conclusion in a case study is likely to be much more convincing and accurate if it is based on several different sources of information, following a corroboratory mode (Yin, 2008), this research used a multitude of data sources. Combining sources of evidence, while shifting between analysis and interpretation, denotes triangulation (Denzin, 1978; Yin, 2008), which is often thought of as a way of guarding against researcher bias (Taylor \& Bogdan, 1984). Throughout the case study, data were gathered during 2011, utilizing interviews with executives and different stakeholders as well as in loco visits for direct observation. Triangulation has been sought both within firms, by comparing the interview responses and in loco visits observations, and between firms, by comparing the responses of inter-related firms, similar to Stevenson and Spring (2009). The research team consisted of four members who jointly conducted the interviews and plant visits, providing another form of triangulation (Taylor \& Bogdan, 1984). Interviews were conducted with 18 senior executives from three different automotive SCs, covering 3 or 4 of their tiers. These interviews were based on a semi-structured questionnaire designed for this purpose (Yin, 2008), respecting the interview protocol adapted from Manuj and Sahin (2011) with five main parts. The first part contained an introduction of the interviewer and the interviewee, an overview of the study's scope and the confidentiality assurance. Then, the demographic data, including the title of the interview participants, their job history and the background of their organization, SC and industry were gathered. The third part contained questions for dealers and automaker's regional sales offices regarding the main lack of flexibilities that limit their resilience and capacity to bet- ter support and meet the demand changes in the marketplace. This part aimed at obtaining the main reasons, the SC members involved and the consequences as well as the possible actions to be developed. The fourth part contained questions for previously identified automakers and suppliers and was based on the same questions as part 3; however, the companies were first asked if they agreed with the view provided by their upstream partners. The last part embraced additional unplanned / floating prompts.

Here, it is worth noting that the tiers (companies) investigated are connected and maintain a client-supplier relationship (or vice versa) in the SC. The dealerships investigated belonged to megadealer groups that accounted for a significant sales volume in Brazil. The interviews followed the demand (upstream) direction in the SC. The respondents at the automakers of each SC helped the researchers during the interviews to identify key first-tier suppliers who could participate in the research. This procedure was also conducted with these first-tier suppliers to identify the second-tier suppliers to be included, similar to Carvalho, Barroso, Machado, Azevedo, and Cruz-Machado (2012) with the Portuguese automotive SC. The main goal was to assemble a representative picture of actors across the main tiers of the SCs. Interviews with executives at the dealers, automaker's regional sales offices, vehicle assembly plants and tier-1 suppliers were face-to-face, lasted between two and four hours and were followed by visits to the plants for direct observation. These interviews included two regional sales executives from the distribution channels of each SC (Car Mega-Dealer group and automaker's regional office), two executives from each automaker's assembly plant (Logistics General Manager and Production Planning Manager for SC A; Production Planning Manager and Procurement Manager for SC B; Production Planning Manager and Logistics General Manager for SC C), and executives from first-tier suppliers (General Manager of an engine plant for SC A; General Manager of a power-steering supplier and General Manager of an alloy wheel supplier for SC B; Production Manager of the seat supplier for SC C). The interviews with tier-2 suppliers lasted one hour and were conducted by telephone. This was the case only for SC A with two executives from second-tier suppliers (director of the electronic injection supplier and director of an engine blocks and crankshafts supplier). A member checking process was also conducted with the same managers to validate the researchers' results findings and analysis (Bloor, 1997). This was accomplished by showing the data analysis to the participants for them to evaluate and provide feedback about the accuracy of the researchers' understanding. This validation process was conducted face to face with the executives. 


\section{RESULTS AND DISCUSSIONS}

This section presents the main empirical findings of the research. The sales demand for vehicles in Brazil is highly variable despite the fact that the Brazilian automotive industry has become a significant global player. The studied SCs suffer from this demand variability across the years, which requires the $\mathrm{SC}$ to build resilience.

SC A produces vehicle models for the low-cost market segment. It has faced a significant demand growth, beyond expectations, for its main vehicle models. As a result, one significant lack of flexibility was identified in a first-tier supplier of the automaker, the engine plant. This supplier could increase its overall output by more than $20 \%$ by implementing flexible labor force journeys and contracts; however, this increase was not sufficient to meet the new demand pattern. Therefore, this first-tier supplier limited the SC's ability to be resilient, resulting in a loss of sales as it could not meet the demand. To meet this new demand requirement, this supplier decided to invest to increase its daily production. According to the General Manager of the Engine Plant, "as soon as this investment is concluded, the lack of flexibility in the SC should move upstream to second-tier suppliers, especially those responsible for the engine blocks and crankshafts". This was also highlighted in the interviews with the Logistics General Manager and the Production Planning Manager for the automaker. Both the automaker and engine supplier of SC A are aware of this possibility and negotiate capacity increases with these second-tier suppliers. However, the Director of the engine blocks and crankshafts supplier was not motivated to do this investment, as it requires a high amount of financial resources for acquiring tools and a long time to start the new production (up to two years). This second-tier supplier is not willing to invest alone in this capacity increase and aims to share this investment as well as the associated risks with the downstream partners. This supplier is afraid of an unforeseen future demand decrease that would make them idle again, as happened in the late 1990 s after a boom in demand and high investments in capacity in the Brazilian automotive industry. Regarding this, he said that "in late 1990 , we trusted in the automaker projections with respect to increased demand, and we made significant investments in resources to support it. However, the positive projections have not materialized. Hence, after this, we revised our strategy and decided to diversify our customer base and reduce our huge dependence from the automakers. Now, it's difficult to go back and revise our strategy to meet this automaker as quick as they want". This negative previous experience between these companies was a clear barrier to overcome an identified lack of flexibility found in SC A. The lack of flexibility in the relationship between these aforementioned SC members reduces the possibility of increasing resilience in the $\mathrm{SC}$, as there is no cooperative / collaborative relationships between them (e.g., by sharing investments and/or risks related to an idle production capacity); this is consistent with Christopher and Peck (2004) and the empirical findings of Stevenson and Spring (2009) and Wieland and Wallenburg (2013).

SC resilience was also seriously compromised by other second-tier suppliers of SC A. The aforementioned increase in demand was stronger for the models and versions with a 1.0-litre engine, but the volume production increase was limited at the automaker vehicle assembly plant due to a lack of this specific engine. Therefore, the $\mathrm{SC}$ resilience was not limited by the engine plant itself but by its electronic injection supplier. This second-tier supplier could not meet the new demand because its additional production capacity was already designated for another customer with higher priority (another automaker that was also the supplier's owner). Regarding this, the engine plant executive stated "it was a wrong strategic decision to have the supply of this component done entirely by a supplier that belongs to an automaker that competes with us in the marketplace. We are now being placed as a second option for them, and we need to review this urgently". As a result, the engine plant increased the production of the 1.6-litre engine, pushing downstream 1.6-litre engines in place of 1.0-litre engines, resulting in a mix flexibility restriction at the dealer level and end-customers who absolved the 1.6 -litre engine vehicles with discounts. This was highlighted in the words of a dealership executive: "customers arrive at the points-of-sale wishing a vehicle model / version with a 1.0-litre engine, as they are low cost. As we do not have them, we make their minds to take a 1.6-litre engine with discounts, which makes the price similar to the ones with a 1.o-litre engine, but shorten our margins". The lack of flexibility in this case results in lower profits. This finding corroborates Pettit, Fiksel and Croxton (2010), where the authors present the importance of the balance between capabilities and vulnerabilities to be resilient, once the level of capability presented by the studied SC was not enough to respond to all vulnerabilities of demand.

The lack of sourcing flexibility at the automaker second-tier supply level of SCA is remarkable, reinforced by the impossibility of finding new suppliers in the short term. The cases were exacerbated by a single sourcing operation, a consequence of the supplier base rationalization trend within the automotive industry's SC. On one hand, this rationalization seeks the benefits of a close relationship that can provide flexibility with a greater willingness on the part of the supplier to cope with change. However, on the other hand, such relationships can make SC 
re-configuration more difficult, creating dependence (Wieland \& Wallenburg, 2013), as observed in this research. This observation reinforces the concerns in the literature regarding this type of relationship in an environment of uncertainty (Sheffi \& Rice, 2005; Lee, Yeung, \& Cheng, 2009), resulting in trade-offs with risk and flexibility in the SC (Stevenson \& Spring, 2009; Juttner \& Maklan, 2011).

SC B produces different vehicle models ranging from a low-cost subcompact model to a highly valued compact model considered sophisticated for the regional market. This SC has also faced an unexpected demand increase. As a result, a lack of flexibilities in the SC was observed in the supply of some components that limited its ability to be resilient regarding two vehicle models. This was the case for air-conditioning and power steering components, as their suppliers had achieved their maximum capacity and could not produce more to attend the automaker's additional orders. Concerning this, the General Manager of the power steering supplier stated that "recently, the demand for these components has grown significantly in the country, and our capacity has not kept pace. We know that we are losing sales. But we need to review it based on our demand forecast for the medium term, since herein, we have a policy that does not like idleness and always seeks to maximize the use of our assets". Thus, as the automaker sales department could not offer dealers more cars with these components, it "pushed" downstream a mix that was not ordered as a way to reverse this mishap. Customers of the low-cost subcompact model were not completely disappointed because dealers were able to configure some of the units at their points of sales with these missing components. However, this action was not successful for the highly valued compact model. In the case of the highly valued compact model, only $60 \%$ of the dealers' orders containing air-conditioning were delivered with the component by the automaker, and the remaining $40 \%$ were delivered without air-conditioning. As customers of this market segment are more demanding of product quality, they are concerned about the late configuration service conducted at the dealerships rather than at the vehicle assembly plants. Regarding this, a dealership executive said that "in this vehicle segment, the customer has become increasingly informed and demanding, no longer accepting solutions that appear to be improvised or poorly done. So, in that case, we lose many sales".

The lack of flexibility in the SC was also observed in the alloy wheels supply, and, as in the air-conditioning and power steering supply, the SC resilience level varied according to the vehicle model. For the cheap, subcompact model, there was a mix flexibility restriction to end-customers because the model was pushed downstream with steel wheels instead of al- loy wheels. As dealers were able to configure the cars with alloy wheels, the chain has demonstrated some resilience for this model. However, as the highly valued compact model could not be pushed downstream with steel wheels due to its basic configuration, the automaker had to reduce its production at the vehicle assembly plant, and the units delivered to dealers were insufficient to meet the demand, resulting in lost sales for this model. In this case, the lack of flexibility completely limited the $\mathrm{SC}$ resilience.

SC B offers an interesting insight, as SC resilience depended on the analyzed product (vehicle model). Considering the low-cost subcompact model, SC's ability to cope with the consequences of the demand change can be considered satisfactory to move its original operations to a more desirable state after being disturbed, as described in Christopher and Peck (2004), Peck (2005) and Ponomarov and Holcomb (2009). The SC managed the demand increase by using different internal flexibility types, such as flexible labor force journeys, as well as external types, such as postponement, sourcing and re-configuration flexibilities. Together they have designed a flexible process that could maintain the operations under the demand disturbance, which is aligned with the flexibility concept for resilience defined in Dinh, Pasman, Gao, and Mannan (2012). However, the same SC was not resilient for the highly valued compact model. Although different flexibility capabilities were observed, the postponement flexibility did not succeed. The lack of this flexibility limited the chain's ability to more adequately meet the customer demand for this vehicle model. On this issue, the same dealership manager quoted earlier said "the market segmentation in the industry seems to be getting more pronounced, i.e., it has become clearer in order to identify distinct groups of end-customers". This sheds new lights on the academic literature of SC resilience, as the same SC may have capabilities to be resilient for one of its product but not for another product.

SC C produces a highly valued compact vehicle model. As its vehicle model is based on many imported components, it was exposed to an unforeseen cost/price increase due to a significant devaluation of the Brazilian monetary currency. The lack of flexibility to address this change resulted in a significant decrease in sales compared to the planned forecast. As a result, the automaker efforts were concentrated on just two of the four original versions, which reduced the mix range offered. These two versions had to use components that were already in the pipeline, further reducing the mix within these two versions. For example, vehicles were produced during the first year with the doors and seat trims that were in stock or with orders already placed (purchased). This prevented customers from or- 
dering available trims in the catalog, restricting their choices to the available trim in the SC pipeline. Regarding this, a Regional Sales office executive from the automaker made a critical statement regarding the variety offered: "the client of this premium trademark is usually demanding, and this lack of more choices has been negative for us and for the whole SC. Hence, we are losing sales to competitors". This was endorsed by the dealers' executive who added: "we cannot be so vulnerable to currency devaluation, and actions should be thought to make us more resilient in the future so that we can continue in the business". This reflects the discontent of this chain member and highlights the need to develop capabilities to make the chain resilient, mainly flexibility because it can help to address volatile periods, as when introducing new products (Sheffi \& Rice, 2005).

Exhibit 1 summarizes the main findings obtained from the three SCs.

\section{Exhibit 1. Summary of main findings}

\begin{tabular}{c|l|l|l|l|l}
\hline SC & Demand change & $\begin{array}{l}\text { Lack of flexibilities that } \\
\text { decreased SC resilience }\end{array}$ & $\begin{array}{l}\text { Flexibilities } \\
\text { observed that built } \\
\text { SC resilience }\end{array}$ & $\begin{array}{l}\text { SC strategies to address lack of } \\
\text { resilience }\end{array}$ & Additional observations \\
\hline A & Huge increase & $\begin{array}{l}\text { Production capacities, } \\
\text { Sourcing and } \\
\text { relationship }\end{array}$ & $\begin{array}{l}\text { Labor force and } \\
\text { contracts }\end{array}$ & $\begin{array}{l}\text { Increased production of 1.6-liter } \\
\text { engine selling vehicles with } \\
\text { discounts }\end{array}$ & $\begin{array}{l}\text { SCA was not resilient, } \\
\text { losing sales and offering a } \\
\text { product mix not accordantly } \\
\text { to the demand }\end{array}$ \\
\hline B & Huge increase & Production capacities & $\begin{array}{l}\text { Sourcing, } \\
\text { postponement and } \\
\text { re-configuration }\end{array}$ & $\begin{array}{l}\text { Labor, relationships, } \\
\text { highly valued compact model. Late } \\
\text { configuration conducted at dealers } \\
\text { for the low-cost subcompact model }\end{array}$ & $\begin{array}{l}\text { Pushed downstream not ordered } \\
\text { high valued, but not for the } \\
\text { model where it lost sales } \\
\text { lowilient for the }\end{array}$ \\
\hline C & Huge decrease & Excess of inventory & - & $\begin{array}{l}\text { Automaker production efforts } \\
\text { were concentrated in just two of } \\
\text { the four original versions }\end{array}$ & Same as SC A
\end{tabular}

\section{FINAL REMARKS}

This paper analyses how three Brazilian automotive SCs cope with unexpected demand changes, building or not building resilience from a flexibility perspective. It addresses a literature gap regarding the need for empirical studies on SC resilience capable of investigating the inter-organizational components of SC flexibility along different tiers. The contribution is especially relevant for business and management researchers, as this topic is relatively new and yet underexplored within these disciplines (Ponis \& Koroni, 2012; Soni, Jain, \& Kumar, 2014).

On one hand, a lack of flexibility was identified along different SC tiers, embracing inclusively tier-2 suppliers, decreasing the SC resilience and resulting in negative consequences such as loss of sales. On the other hand, different flexibility capabilities were identified, such as postponing part of the vehicle final configuration from automakers assembly plants to dealer's points of sales, which increased the SC resilience. These findings reinforce the need to extend the flexibility academic debate to include the SC, a need that is highlighted in the literature (e.g., Stevenson \& Spring, 2007; Chandra \& Grabis, 2009; Fatemi, 2010; Moon, Ying, \& Ngai, 2012). The findings also cor- roborate Christopher and Peck (2004), Sheffi and Rice (2005), Juttner and Maklan (2011) concerning the importance of flexibility to achieve resilience.

The research findings also shed new lights on the academic literature. SC resilience can vary according to its products, as the same SC may have capabilities to be resilient for one of its products but not for another product. This was observed in SC B regarding the low-cost, subcompact model and the highly valued, compact model in different moments (air-conditioning, alloy-wheel and power-steering supply).

A flexible SC should be designed to increase SC resilience to cope with unforeseen events; in this research, the demand change. This requires flexibility not only at a firm level (e.g., internal manufacturing flexibility) but also at a customer - supplier flexibility level. Although different flexibility capabilities were identified at the customer-supplier level, our research findings indicate that SC members focused more on flexibility at the firm level. This observation corroborates Sánchez and Pérez (2005) findings in the Spanish Automotive Industry and reinforces the fact that companies might miss opportunities to improve competitiveness by underestimating customer-supplier flexibility capabilities. Additionally, the 
studied SCs were reactive in nature to the mishaps, once they applied reactive SC strategies to respond to vulnerability (Wieland \& Wallenburg, 2013). None of the SCs used flexibility to proactively seize opportunities, which explains the low resilience observed. This corroborates Datta, Christopher and Allen (2007), where SC Resilience is not just the ability to recover from mishaps but is a proactive, structured and integrated exploration of capabilities within the SC to cope with unforeseen events. The effective use of flexibility concurrently for both proactive and reactive purposes was already studied in the printed circuit board industry (Sawhney, 2006) and should be better understood in the Brazilian Automotive Industry context, as it can become a competitive advantage from a SC flexibility perspective. Further research in this area is required.

In addition to advancing the academic debate on SC resilience and flexibility at a SC level by investigating the under-researched inter-organizational dimension of flexibility, this research is particularly relevant to practitioners. With the increasing synchronization of SCs, bottlenecks in supplying operations can become serious constraints in delivering products to customers, decreasing the SC resilience. Therefore, an understanding of how SCs can be designed to increase the overall level of flexibility, building resilience, and how factors within and between the individual SC partners may limit this flexibility, thus decreasing resilience, are crucial for SC managers across many industries.

This research has some limitations that open opportunities for additional future research. First, structured interviews were conducted with just 18 key executives. Given the key role that the interviewees played in each SC, we argue that the relatively low number of executives interviewed does not pose a major constraint on the validity of our findings, in particular because we were able to triangulate the findings. Another limitation regards the fact that the case study was conducted on three SCs in the automotive industry of an emergent economy; this provides evidence about a single industry and country. Finally, the research was focused mainly on the flexibility capability needed to better support and meet the demand changes, as the high vulnerability of demand change in the Brazilian automotive market is an important mishap. However, other mishaps exist and may offer additional insights in future research. As comparable empirical studies in the literature are still rare, the present research is only an initial step towards the investigation of a topic that is likely to grow in importance, as companies' successes depend increasingly more on their SC. Future studies may want to make a more systematic and focused investigation and test and expand on our findings with the goal of filling the theory and practice gap in this area.

\section{REFERENCES}

Anfavea. (2014). Desempenho do setor automobilístico em maio. Brazilian Automaker's Association. Retrieved on June 14, 2014 from http:// www.anfavea.com.br.

Avittathur, B., \& Swamidass, P. (2007). Matching plant flexibility and supplier flexibility: Lessons from small suppliers of U.S. manufacturing plants in India. Journal of Operations Management, 25(3), 717-735.

Berry, W. L., \& Cooper, M. C. (1999). Manufacturing flexibility: methods for measuring the impact of product variety on performance in process industries. Journal of Operation Management, 17(2), 163-178.

Bakshi, N., \& Kleindorfer, P. (2009). Co-opetition and investment for supply-chain resilience. Production and Operations Management, 18(6), 583-603.

Bhamra, R., Dani, S., \& Burnard, K. (2011). Resilience: the concept, a literature review and future directions. International Journal of Production Research, 49(18), 5375-5393.

Bloor, M. (1997). Techniques of Validation in Qualitative Research: a Critical Commentary. In: Miller G. \& Dingwall R. (eds) Context and Method in Qualitative Research. London: SAGE, pp. 37-50.

Carvalho, H., Barroso, A., Machado, V., Azevedo, S., \& Cruz-Machado, V. (2012). Supply chain redesign for resilience using simulation. Computers \& Industrial Engineering, 62(1), 329-341.

Chandra, C., \& Grabis, J. (2009). Role of flexibility in supply chain design and modeling-Introduction to the special issue. International Journal of Management Science, 37(4),743-745.

Chang S., Chen, R., Lin, R., Tien, S., \& Sheu C. (2006). Supplier involvement and manufacturing flexibility. Technovation, 26(10)1136-1146.

Christopher, M., \& Lee, H. (2004). Mitigating supply chain risk through improved confidence. International Journal of Physical Distribution \& Logistics Management, 34(5), 388-396.

Christopher, M., \& Peck, H. (2004). Building the resilient supply chain. The International Journal of Logistics Management, 15(2), 1-13.

Christopher, M., \& Towill, D. (2001). An integrated model for the design of agile supply chains. International Journal of Physical Distribution \& Logistics Management, 31(4), 235-246.

Datta, P., Christopher, M., \& Allen, P. (2007). Agent-based modelling of complex production/distribution systems to improve resilience. International Journal of Logistics Research and Applications, 10(3), 187-203.

De Toni, A., \& Tonchia, S. (1998). Manufacturing flexibility: a literature review. International Journal of Production Research, 36(6), 1587-1617.

Denzin N. K. (1978). The logic of naturalistic inquiry. In: Denzin NK, editor. Sociological methods, a sourcebook. New York: McGraw-Hill, pp. 54- 73 .

Dinh, L., Pasman, H., Gao, X., \& Mannan, M. (2012). Resilience engineering of industrial processes: principles and contributing factors. Journal of Loss Prevention in the Process Industries, 25(2), 233-241.

Fatemi, M. (2010). Supply chain flexibility: definition and review. European Journal of Economics, Finance and Administrative Sciences, 20(20), $140-147$.

Fisher, M. (1997). What is the right supply chain for your product? Harvard Business Review, 75(2), 105-116.

Fiksel, J. (2006). Sustainability and resilience: toward a systems approach. Sustainability: Science, Practice, \& Policy, 2(2), 14-21. 
Gosling, J., Purvis, L., \& Naim, M. (2010). Supply chain flexibility as a determinant of supplier selection. International Journal of Production Economics, 128(1), 11-21.

Graves, S., \& Tomlin, B. (2003). Process flexibility in supply chains. Management Science, 49(7), 907-919.

Juttner, U., \& Maklan, S. (2011). Supply chain resilience in the global financial crisis: an empirical study. Supply Chain Management: An International Journal, 16(4), 246-259.

Klibi, W., \& Martel, A. (2012). Modeling approaches for the design of resilient supply chain networks under disruptions. International Journal of Production Economics, 135(2), 882-898.

Lee, H. (2002). Aligning supply chain strategies with product uncertainties. California Management Review, 44(3), 105-119.

Lee, P., Yeung, A., \& Edwin Cheng, T. (2009). Supplier alliances and environmental uncertainty: An empirical study. International Journal of Production Economics, 120(1), 190-204.

Liao, Y., Hong, P., \& Rao, S. S. (2010). Supply management, supply flexibility and performance outcomes: an empirical investigation of manufacturing firms. Journal of Supply Chain Management, 46(3), 6-22.

Manuj, I., \& Sahin, F. (2011). A model of supply chain and supply chain decision-making complexity. International Journal of Physical Distribution \& Logistics Management, 41(5), 511-549.

Moon, K., Ying, C., \& Ngai, E. (2012). An instrument for measuring supply chain flexibility for the textile and clothing companies. European Journal of Operational Research, 222(2), 191-203.

Pettit, T., Fiksel, J., \& Croxton, K. (2010). Ensuring supply chain resilience: development of a conceptual framework. Journal of business logistics, 31(1), 1-21.

Peck, H. (2005). Drivers of supply chain vulnerability: an integrated framework. International Journal of Physical Distribution \& Logistics Management, 35(4), 210-232.

Pires, S., \& Sacomano Neto, M. (2008). New configurations in supply chains: the case of a condominium in Brazil's automotive industry. Supply Chain Management: an International Journal, 13(4), 328-334.

Pires, S., Weinstock, M., \& Andrade, G. (2013). A study on supply chain risk management in the Brazilian automotive industry, Proceedings of the EUROMA 2013. Anais. Dublin, Ireland: EUROMA.

Ponis, S., \& Koronis, E. (2012). Supply chain resilience: definition of concept and its formative elements. Journal of Applied Business Research, 28(5), 921-930.

Ponomarov, S., \& Holcomb, M. (2009). Understanding the concept of supply chain resilience. The International Journal of Logistics Management, 20(1), 124-143.

Qi, Y., Boyer, K., \& Zhao, X. (2009). Supply chain strategy, product characteristics, and performance impact: evidence from Chinese manufacturers. Decision Sciences, 40(4), 667-695.
Randall, T., \& Ulrich, K. (2001). Product variety, supply chain structure, and firm performance: analysis of the U.S. bicycle industry. Management Science, 47(12), 1588-1604.

Sawhney, R. (2006). Interplay between uncertainty and flexibility across the value-chain: towards a transformation model of manufacturing flexibility. Journal of Operations Management, 24(5), 476-493.

Sánchez, A., \& Pérez, M. (2005). Supply chain flexibility and firm performance: a conceptual model and empirical study in the automotive industry. International Journal of Operations \& Production Management, $25(7), 681-700$.

Scavarda, L. F., Reichhart, A., Hamacher, S., \& Holweg, M. (2010). Managing product variety in emerging markets. International Journal of Operations \& Production Management, 30(2), 205-224.

Sheffi, Y. (2001). Supply chain management under the threat of international terrorism. International Journal of Logistics Management, 12,(2), $1-11$.

Sheffi, Y., \& Rice, J. (2005). A supply chain view of the resilient enterprise. Mit Sloan Management Review, 47(1), .41-48.

Slack, N. (1987). The flexibility of manufacturing systems. International Journal of Operations \& Production Management, 7(4), 35-45.

Soni, U., Jain, V., \& Kumar, S. (2014). Measuring supply chain resilience using a deterministic modeling approach. Computers \& Industrial Engineering, $74, .11-25$.

Stevenson, M., \& Spring, M. (2007). Flexibility from a supply chain perspective: definition and review. International Journal of Operations \& Production Management, 27(7), 685-713.

Stevenson, M., \& Spring, M. (2009). Supply chain flexibility: an inter-firm empirical study. International Journal of Operations \& Production Management, 29(9), 946-971.

Suarez, F., Cusumano, M., \& Fine, C. (1996). An empirical study of manufacturing flexibility in printed circuit board assembly. Operations Research, 44(1), 223-240.

Taylor, S. J., \& Bogdan, R. (1984). Introduction to qualitative research methods: The search for meanings. New York: John Wiley \& Sons. 337 p.

Tsay, A., \& Lovejoy, W. (1999). Quantity flexibility contracts and supply chain performance. Manufacturing \& Service Operations Management, 1(2), 89-111.

Upton, D. M. (1994). The management of manufacturing flexibility. California Management Review, 36(2), 72-89.

Voss, C., Tsikriktis, N., \& Frohlich, M. (2002). Case research in operations management. International Journal of Operations \& Production Management, 22(2), 195-219.

Wieland, A., \& Wallenburg, C. (2013). The influence of relational competencies on supply chain resilience: a relational view. International Journal of Physical Distribution \& Logistics Management, 43(4), 300-320.

Yin, R. (2008). Case Study Research: designs and methods, 3rd, Sage Publications, London. 219 p. 